\title{
PENGARUH METODE EDUTAINMENT TERHADAP KEMAMPUAN KLASIFIKASI ANAK TAMAN KANAK-KANAK
}

\author{
Sang Ayu Putu Laksmi Uttari ${ }^{1}$, Putu Aditya Antara ${ }^{2}$, Putu Rahayu Ujianti ${ }^{3}$ \\ 1,2,3 Jurusan Pendidikan Guru Pendidikan Anak Usia Dini \\ Fakultas Ilmu Pendidikan \\ Universitas Pendidikan Ganesha \\ Singaraja, Indonesia
}
e-mail: ayulaksmiuttari@gmail.com¹, putuaditya.antara@undiksha.ac.id², puturahayuujianti@undiksha.ac.id ${ }^{3}$

\begin{abstract}
Abstrak
Penelitian ini bertujuan untuk mengetahui pengaruh metode edutainment terhadap kemampuan klasifikasi anak kelompok A Taman Kanak-Kanak Gugus IV Kecamatan Buleleng. Jenis penelitian ini adalah quasi experiment dengan desain non-equivalent control group design. Populasi penelitian adalah seluruh anak kelompok A Taman Kanak-Kanak Gugus IV Kecamatan Buleleng yang berjumlah 96 orang. Dalam menentukan sampel digunakan teknik cluster sampling. Adapun sampel penelitian ini adalah kelompok A TKK Santo Rafael sejumlah 19 orang sebagai kelompok eksperimen dan kelompok A TK Ganesa sejumlah 16 orang sebagai kelompok kontrol. Data kemampuan klasifikasi dikumpulkan dengan metode observasi menggunakan instrumen lembar observasi. Data yang diperoleh dianalisis dengan teknik statistik deskriptif dan statistik inferensial (uji-t) dengan rumus polled varians. Berdasarkan hasil analisis deskriptif, rata-rata kemampuan klasifikasi pada kelompok eksperimen sebesar 58,53 yang termasuk kategori sangat tinggi, sedangkan pada kelompok kontrol sebesar 38,44 yang termasuk kategori rendah. Dari hasil analisis dengan uji-t diperoleh $t_{\text {hitung }}$ sebesar 9,761 dan $t_{\text {tabel }}$ pada taraf signifikansi $5 \%$ dengan $d k=33$ sebesar 2,042, sehingga $t_{\text {hitung }}>t_{\text {tabel }}$, maka $\mathrm{H}_{0}$ ditolak dan $\mathrm{H}_{1}$ diterima. Artinya terdapat pengaruh yang signifikan metode edutainment terhadap kemampuan klasifikasi anak kelompok A Taman Kanak-Kanak Gugus IV Kecamatan Buleleng Tahun Pelajaran $2017 / 2018$.
\end{abstract}

Kata-kata kunci: kemampuan klasifikasi, metode edutainment, taman kanak-kanak.

\begin{abstract}
This research is aimed to find out the effect of edutainment method for children's classification ability at group A of Kindergarten in Gugus IV of Buleleng Sub-district. This research belongs to quasi experiment with non equivalent control group. The population of this study is 96 children's of Kindergarten at group A in Gugus IV of Buleleng Sub-district. This study makes use of cluster sampling technique in determining the sample of the study. The followings are the sample of the research: 19 children's of group A in TKK Santo Rafael as the experiment group and 16 children's of group A in TK Ganesa as the control group. The data of classification ability is collected by observation method which uses an instrument called observation sheet. The obtained data is analyzed by using the technique of descriptive statistic and inferential statistic (t-test) with the formula of polled varians. Based on the result of descriptive analysis, the average in experiment group is 58,53 in which it can be categorized as extremely high category, whereas the average in control group is 38,44 that can be categorized as low category. From the result of analysis which uses t-test, it is obtained the $t_{\text {count }}$ is 9,761 and $t_{\text {table }}$ in the level of significance is $5 \%$ with $d k=33$ is about 2,042 , it can be concluded that $t_{\text {count }}>t_{\text {table }}$, so $H_{0}$ is refused and $H_{1}$ is accepted. It means that there is significant effect of edutainment method for children's classification ability at group $A$ of Kindergarten in Gugus IV of Buleleng Sub-district in the academic year of 2017/ 2018.
\end{abstract}

Keywords: classification ability, edutainment method, kindergarten. 


\section{PENDAHULUAN}

Kognitif merupakan salah satu aspek yang penting distimulasi dalam perkembangan anak. Kognitif adalah proses yang terjadi secara internal di dalam pusat susunan syaraf pada waktu manusia sedang berpikir (Gagne dalam Jamaris, 2006:8). Ambara, dkk (2014:16) juga menyatakan "kognitif adalah suatu proses berpikir, daya menghubungkan serta kemampuan menilai dan mempertimbangkan". Aspek kognitif pada dasarnya diarahkan untuk meningkatkan kemampuan berpikir anak, sehingga anak memiliki pondasi untuk mampu berpikir kritis, logis, dan matematis. Aspek kognitif memiliki lingkup perkembangan salah satunya berpikir logis. Dalam ranah berpikir logis terdapat tugas-tugas perkembangan, salah satunya adalah kemampuan klasifikasi. Charleswort dan Lind (dalam Tirtayani, dkk (2014:12) menyatakan bahwa klasifikasi atau pengelompokkan merupakan salah satu kegiatan yang paling mendasar dan alami untuk anak. Sebelum melakukan penambahan dan pengurangan formal, anak perlu belajar tentang kumpulan dan bagaimana mereka dapat memisahkan dan menggabungkan suatu objek. Artinya anak-anak harus berlatih memilah (memisahkan) dan mengelompokkan (menggabungkan).

Klasifikasi atau pengelompokkan adalah salah satu proses dasar yang anakanak gunakan untuk mengembangkan kemampuan berlogika. Pengelompokkan merupakan metode menempatkan objek yang serupa di kelas atau kategori yang sama. Anak terlebih dahulu harus tahu penampilan benda-benda, seperti bentuk, warna, dan ukuran. Lalu bisa mengetahui benda yang serupa dan berbeda. Begitu anak sudah mulai mengamati sifat sama atau berbeda dari objek, anak mulai bisa memisahkan dan mengelompokkan (Beaty, 2013:275). Pendapat lain dari Maslichah (dalam Wibawati, 2014:29) yang mendefinisikan bahwa kemampuan klasifikasi atau penggolongan adalah kemampuan untuk melihat persamaan dan perbedaan suatu objek sehingga dengan dasar tersebut objek dapat dikelompokkan atau dipisahkan dari orang lain.

Pengembangan kemampuan klasifikasi memiliki beberapa tujuan yaitu kemampuan klasifikasi amat berguna bagi anak untuk mengembangkan kemampuannya dalam menyatukan beberapa informasi yang berbeda yang ia dapatkan dari lingkungan atau yang ia punyai di kepalanya (Hildayani, dkk. dalam Wibawati, 2014:36). Paciorek dan Joyce (dalam Wibawati, 2014:35) juga menyatakan sebelum anak bisa menjumlah atau bahkan menghitung, mereka harus membangun konsep tentang matematika yang tidak dapat diajarkan secara langsung. Konsep yang akan mendukung matematika umum dalam kehidupan mendatang termasuk urutan dan rangkaian, seriasi, dan klasifikasi. Dari tujuan tersebut, maka penting untuk menstimulasi perkembangan kemampuan klasifikasi anak, karena dengan kemampuan klasifikasi yang baik anak memiliki dasar yang baik pula dalam mendukung perkembangan pra-matematika dan perkembangan pemikiran logisnya.

Tugas perkembangan kemampuan klasifikasi anak usia 4-5 tahun tercantum pada Permendikbud No. 137 Tahun 2014 yaitu mengklasifikasikan benda berdasarkan fungsi, bentuk atau warna atau ukuran, serta mengklasifikasikan benda ke dalam kelompok yang sama atau sejenis dengan 2 variasi. Hal tersebut juga didukung oleh Beaty (2013:285) yang menyatakan "begitu anak terbiasa dengan berbagai ukuran, bentuk, dan warna di seluruh eksplorasinya dalam mengidentifikasi dan menyebutkan objekobjek, biarkan anak menerapkan kemampuan klasifikasi dengan lebih dari satu sifat". Pendapat lain dari Fauziddin (2015:15) yaitu "pada anak usia 4-5 tahun, anak diharapkan mampu mengklasifikasikan benda berdasarkan bentuk atau warna atau ukuran atau mengelompokkan benda berdasarkan dua atribut sekaligus".

Namun kenyataannya, tugas-tugas perkembangan kemampuan klasifikasi 
tersebut belum dapat terpenuhi dengan baik, sehingga kemampuan klasifikasi masih menjadi suatu permasalahan dalam proses pembelajaran. Hal ini tampak berdasarkan observasi di Taman KanakKanak Gugus IV Kecamatan Buleleng, yaitu pada kelompok A. Masih terdapat anak yang belum mengenal dengan baik ciri-ciri, persamaan objek, belum mampu membedakan objek dengan baik, serta belum mampu memilah dan mengelompokkan objek sesuai dengan karakteristiknya. Ini tampak ketika anak menggabungkan objek yang memiliki karakteristik berbeda, seperti bentuk persegi dengan bentuk persegi panjang, warna merah dengan warna orange, serta segitiga berwarna merah dengan segitiga berwarna kuning. Dari hasil observasi dan wawancara lebih lanjut, diketahui penyebab timbulnya permasalahan ini yaitu pembelajaran yang masih terpusat pada guru dan penggunaan metode pembelajaran yang didominasi dengan metode ceramah dan tanya jawab.

Berdasarkan permasalahan yang ditemui di kelompok A Taman Kanak-Kanak Gugus IV Kecamatan Buleleng, maka perlu dilakukan perbaikan dalam rangka pemecahan masalah. Salah satu solusi yang dapat digunakan untuk memecahkan permasalahan terkait rendahnya kemampuan klasifikasi anak yaitu metode edutainment. Metode edutainment adalah metode yang dapat menjadikan suasana belajar menyenangkan, sehingga anak tidak merasa bahwa ia sedang belajar, karena pembelajaran di desain dengan menyelipkan hiburan dan aktivitas bermain. Prihadi (dalam Maghfuro dan Febrita, 2014:3) mendefinisikan bahwa metode edutainment adalah gabungan antara educational dan entertainment yang di dalamnya terdapat games, musik, film, gerak dan selipan humor. Putala dan Martin (2016:75) juga menyatakan "edutainment adalah bentuk transfer pengetahuan dengan unsur hiburan yang sering digunakan dalam pendidikan pra-sekolah dan pendidikan anak usia dini untuk merangsang perkembangan anak".

Metode edutainment adalah salah satu metode yang cocok diterapkan pada pembelajaran anak usia dini. Hal ini sesuai dengan prinsip-prinsip dalam pendidikan anak usia dini diantaranya belajar melalui bermain dan menggunakan berbagai media atau permainan edukatif dan sumber belajar (Suyadi, 2010:12). Dalam metode edutainment pembelajaran dilakukan secara menyenangkan melalui aktivitas bermain. Aktivitas bermain juga melibatkan gerak dan musik. Gerak yang dilakukan adalah gerak bebas sesuai dengan imajinasi anak atau yang disebut dengan creative movement. Hal ini ditegaskan oleh Antara (2015:33) yang menyatakan bahwa creative movement adalah gerak yang dikombinasikan untuk mengekspresikan pengalaman batin dan mengungkapkan perasaan seseorang serta dilakukan dengan memberikan kebebasan pada anak untuk bergerak sesuai dengan imajinasinya. Selain itu, metode edutainment juga melibatkan penggunaan media pembelajaran, yaitu video.

Terdapat beberapa kelebihan dari metode edutainment. Roqib (dalam Maghfuro dan Febrita, 2014:3) menyatakan bahwa metode edutainment dapat membuat anak merasa senang dan membuat belajar menjadi terasa lebih mudah, memperkuat pemahaman materi pembelajaran karena mendesain pembelajaran dengan pemberian selipan humor atau permainan edukatif. Metode edutainment juga melibatkan tiga modalitas belajar, yaitu auditori, visual, dan kinestetik. Penelitian Magnesen (dalam Suyadi, 2010:236), menyatakan otak lebih cepat menangkap informasi yang berasal dari modalitas visual yang bergerak. Hasil penelitiannya menunjukkan otak menangkap 90\% informasi melalui melihat, mengucapkan, dan melakukan. Belajar dengan auditori, visual, dan kinestetik akan membuat anak lebih mudah dalam menangkap esensi dari proses pembelajaran. Sehingga melalui metode edutainment anak akan lebih mudah memahami materi pembelajaran yang dapat mendukung perkembangan kemampuan anak. Hal senada diungkapkan oleh Hamid (2011:20) yaitu edutainment adalah suatu cara untuk membuat proses pendidikan dan pengajaran bisa menjadi begitu menyenangkan, sehingga para siswa dapat dengan mudah menangkap esensi 
dari pembelajaran itu sendiri, tanpa merasa bahwa mereka tengah belajar.

$$
\text { Metode edutainment dapat }
$$

menstimulasi kemampuan anak, khususnya kemampuan klasifikasi. Hal ini karena prinsip-prinsip metode edutainment sesuai dengan langkah-langkah klasifikasi. Adapun prinsip yang dimaksud adalah mengembangkan emosi positif dan menghargai gaya dan modalitas belajar anak (Fadlillah, 2014:4). Pembelajaran yang menarik dan menyenangkan dapat menimbulkan emosi positif. "Ketika suatu pelajaran melibatkan emosi positif yang kuat, umumnya pelajaran tersebut akan terekam dengan kuat pula dalam ingatan" (Suyadi, 2010:229). Fitrihana (dalam Suyadi, 2010:228) juga berpendapat bahwa suasana gembira akan mempengaruhi cara otak dalam memproses, menyimpan, dan mengambil informasi dengan mudah. Metode edutainment menyajikan pembelajaran klasifikasi melalui video dan aktivitas bermain. Video mempunyai daya tarik tersendiri sehingga anak dapat fokus pada materi yang disampaikan. Melalui video tersebut, anak akan mengenal dan lebih mudah mengingat ciri-ciri dari objekobjek klasifikasi. Sedangkan aktivitas bermain memfasilitasi anak dalam melakukan kegiatan klasifikasi. Karena agar bisa mengklasifikasikan benda anak harus terlibat dan melakukannya sendiri.

Hal tersebut sesuai dengan langkah klasifikasi yang diungkapkan Waluyo, dkk (dalam Wibawati, 2014:37) yaitu mengenali ciri objek dengan diperlihatkan terhadap bendanya, melihat persamaan dan perbedaan objek, memilih atribut klasifikasi yang diikuti dengan kegiatan mengklasifikasikan. Ini juga terkait dengan prinsip kedua yaitu menghargai gaya dan modlitas belajar anak. Mengenali ciri-ciri objek dapat dilakukan secara auditori dan visual melalui video dan benda konkret, melihat persamaan dan perbedaan objek juga dilakukan secara visual melalui video dan benda konkret, serta mengklasifikasikan objek dilakukan secara visual dan kinestetik melalui aktivitas bermain.

Mengingat pentingnya kemampuan klasifikasi untuk distimulasi, sehingga perlu dilakukan pemecahan masalah berupa pembelajaran dengan metode edutainment. Maka dari itu, dilakukan penelitian berjudul "Pengaruh Metode Edutainment Terhadap Kemampuan Klasifikasi Anak Kelompok A Taman Kanak-Kanak Gugus IV Kecamatan Buleleng Tahun Pelajaran 2017/2018".

Penelitian ini bertujuan untuk mengetahui pengaruh yang signifikan metode edutainment terhadap kemampuan klasifikasi anak kelompok A Taman KanakKanak Gugus IV Kecamatan Buleleng Tahun Pelajaran 2017/2018.

\section{METODE}

Penelitian ini dilaksanakan di Taman Kanak-Kanak Gugus IV Kecamatan Buleleng pada semester genap tahun 2017/2018. Penelitian ini merupakan penelitian eksperimen jenis quasi experiment, karena tidak semua variabel dan kondisi eksperimen dapat diatur dan dikontrol secara ketat Adapun desain yang digunakan yaitu non-equivalent control group design. Dengan desain ini, subjek penelitian tidak dipilih secara acak untuk dilibatkan dalam kelompok eksperimen dan kelompok kontrol. Penelitian ini dilaksanakan melalui tiga tahap yaitu: tahap persiapan, tahap pelaksanaan, dan tahap akhir eksperimen.

Populasi merupakan semua subjek pada suatu penelitian. Adapun populasi pada penelitian ini adalah seluruh anak kelompok A Gugus IV Kecamatan Buleleng Tahun Pelajaran 2017/2018 sejumlah 96 orang. Dari populasi yang tersedia, kemudian ditentukan sampel. Sampel merupakan sebagian dari populasi yang diambil, yang mewakili seluruh populasi. Dalam menentukan sampel teknik yang digunakan adalah cluster sampling. Teknik cluster digunakan apabila populasi atau sampel yang tersedia adalah berupa unitunit rumpun dalam populasi. Berdasarkan pemilihan sampel dengan teknik cluster sampling, diperoleh kelompok A TKK Santo Rafael sejumlah 19 orang sebagai kelompok eksperimen, dan kelompok A TK Ganesa sejumlah 16 orang sebagai kelompok kontrol.

Data kemampuan klasifikasi dikumpulkan dengan metode observasi menggunakan instrumen kemampuan klasifikasi sejumlah 22 butir. Instrumen 
yang akan digunakan, terlebih dahulu diuji validitas isi, validitas butir, serta reliabilitasnya. Pengujian validitas isi dilakukan agar isi instrumen sesuai dengan teori dan mendapatkan kualitas instrumen yang baik. Pada uji validitas isi dilakukan uji judges. Pengujian dilakukan oleh dua judges. Adapun judges yang menguji validitas isi instrumen kemampuan klasifikasi yaitu Bapak Komang Sujendra Diputra, M.Pd., yang merupakan dosen
PGSD Undiksha, pengampu mata kuliah matematika, dan Bapak Dr. I Made Tegeh, S.Pd., M.Pd., yang merupakan dosen jurusan Teknologi Pendidikan Undiksha yang juga pernah mengampu mata kuliah media dan sumber belajar di jurusan PG PAUD. Kriteria yang digunakan sebagai pedoman pengujian validitas isi instrumen kemampuan klasifikasi dapat dilihat pada Tabel 1 sebagai berikut.

Tabel 1. Kriteria Validitas Isi Instrumen Kemampuan Klasifikasi

\begin{tabular}{cc}
\hline Skor & Validasi \\
\hline $0,80-1,00$ & Sangat Tinggi \\
$0,60-0,79$ & Tinggi \\
$0,40-0,59$ & Sedang \\
$0,20-0,39$ & Rendah \\
$0,00-0,19$ & Sangat Rendah \\
\hline
\end{tabular}

Setelah dilakukan uji validitas isi, dilanjutkan dengan pengujian validitas butir instrumen. Pengujian dilakukan dengan menguji cobakan instrumen di lapangan. Adapun hasil uji coba dianalisis menggunakan rumus korelasi product moment. Kriteria pengujian butir instrumen adalah butir dikatakan valid jika $r_{x y}>r_{\text {tabel }}$.
Pengujian dilanjutkan dengan uji reliabilitas untuk mengetahui keajegan instrumen yang digunakan. Uji reliabilitas dilakukan dengan menggunakan rumus alfa-cronbach. Adapun kriteria reliabilitas instrumen kemampuan klasifikasi dapat dilihat pada Tabel 2 sebagai berikut.

Tabel 2. Kriteria Reliabilitas Instrumen Kemampuan Klasifikasi

\begin{tabular}{cc}
\hline Batas Koefisien Reliabilitas $(r)$ & Kriteria \\
\hline $0,00<r \leq 0,20$ & Derajat reliabilitas sangat rendah \\
$0,20<r \leq 0,40$ & Derajat reliabilitas rendah \\
$0,40<r \leq 0,60$ & Derajat reliabilitas sedang \\
$0,60<r \leq 0,80$ & Derajat reliabilitas tinggi \\
$0,80<r \leq 1,00$ & Derajat reliabilitas sangat tinggi \\
\hline
\end{tabular}

Data yang diperoleh dianalisis dengan teknik statistik deskriptif dan statistik inferensial. Statistik deskriptif digunakan untuk menentukan mean, median, modus, standar deviasi, dan varians. Sedangkan statistik inferensial digunakan untuk menentukan normalitas, homogenitas, dan melakukan pengujian hipotesis dengan uji-t. Rumus uji-t yang digunakan yaitu polled varians.

\section{HASIL DAN PEMBAHASAN}

Data kemampuan klasifikasi anak terlebih dahulu dianalisis dengan teknik statistik deskriptif yang digunakan untuk menganalisis data dengan cara mendeskripsikan atau menggambarkan data yang telah terkumpul. Statistik deskriptif digunakan untuk menghitung mean, median, modus, standar deviasi, dan varians. Dari analisis dengan statistik deskriptif diperoleh mean, median, modus, standar deviasi, dan varians pada kelompok eksperimen dan kelompok kontrol. Adapun ringkasan hasil analisis deskriptif skor 
kemampuan klasifikasi pada kelompok pada Tabel 3 sebagai berikut. eksperimen dan kelompok kontrol disajikan

Tabel 3. Ringkasan Hasil Analisis Deskriptif Skor Kemampuan Klasifikasi

\begin{tabular}{ccccc}
\hline \multirow{2}{*}{ Data Statistik } & \multicolumn{2}{c}{ Kelompok Eksperimen } & \multicolumn{2}{c}{ Kelompok Kontrol } \\
& Pre-Test & Post-Test & Pre-Test & Post-Test \\
\hline Mean & 32,95 & 58,53 & 32,31 & 38,44 \\
Median & 32,00 & 61,00 & 31,00 & 37,50 \\
Modus & 31,00 & 65,00 & 30,00 & 36,00 \\
Standar Deviasi & 3,822 & 6,875 & 3,945 & 4,926 \\
Varians & 14,608 & 47,263 & 15,562 & 24,262 \\
\hline
\end{tabular}

Merujuk pada Tabel 3, diperoleh mean pre-test kelompok eskperimen sebesar 32,95. Median 32,00, modus 31,00 , standar deviasi 3,822 , dan varians 14,608. Jika mean pada pre-test kelompok eksperimen dikonversikan ke dalam perhitungan skala lima termasuk dalam kategori sangat rendah. Pada post-test kelompok eksperimen diperoleh mean sebesar 58,53, median 61,00, modus 65,00 , standar deviasi 6,875 , dan varians 47,263. Jika mean post-test kelompok eksperimen dikonversikan ke dalam perhitungan skala lima termasuk kategori sangat tinggi. Sedangkan pada kelompok kontrol diperoleh mean pada pre-test sebesar 32,31, median 31,00, modus 30,00 , standar deviasi 3,945 , dan varians
15,562. Jika mean pre-test kelompok kontrol dikonversikan ke dalam perhitungan skala lima termasuk kategori sangat rendah. Pada post-test kelompok kontrol diperoleh mean sebesar 38,44, median 37,50, modus 36,00, standar deviasi 4,926, dan varians 24,262. Jika dikonversikan ke dalam perhitungan skala lima termasuk kategori rendah. Setelah dilakukan analisis deskriptif, maka dilakukan pengujian asumsi sebelum menguji hipotesis. Adapun pengujian asumsi yang dilakukan yaitu uji normalitas dan uji homogenitas. Ringkasan hasil uji normalitas kelompok eksperimen dan kelompok kontrol dapat dilihat pada Tabel 4 sebagai berikut.

Tabel 4. Ringkasan Hasil Uji Normalitas Sebaran Data Kemampuan Klasifikasi

\begin{tabular}{ccccc}
\hline \multicolumn{2}{c}{ Kelompok } & $D_{\text {hitung }}$ & $D_{\text {tabel }}$ & Keterangan \\
\hline \multirow{2}{*}{ Eksperimen } & Pre-test & 0,180 & 0,301 & \multirow{2}{*}{ Normal } \\
& Post-test & 0,216 & 0,301 & \\
\multirow{2}{*}{ Kontrol } & Pre-test & 0,192 & 0,327 & \multirow{2}{*}{ Normal } \\
& Post-test & 0,206 & 0,327 & \\
\hline
\end{tabular}

Berdasarkan uji normalitas menggunakan Kolmogorov-Smirnov, diperoleh $D_{\text {hitung }}$ pada pre-test eksperimen sebesar 0,180 dan $D_{\text {tabel }} 0,301$, sehingga $D_{\text {hitung }}<D_{\text {tabel, }}$ artinya data pre-test kemampuan klasifikasi kelompok eksperimen berdistribusi normal. Pada post-test kelompok eksperimen diperoleh $D_{\text {hitung }}$ sebesar 0,216 dan $D_{\text {tabel }} 0,301$, maka $D_{\text {hitung }}<D_{\text {tabel, }}$ artinya data post-test kemampuan klasifikasi kelompok eksperimen berdistribusi normal.
Sedangkan pada kelompok kontrol, diperoleh $D_{\text {hitung }}$ pada pre-test sebesar 0,192 dan $D_{\text {tabel }} 0,327$, maka $D_{\text {hitung }}<D_{\text {tabel }}$, artinya data pre-test kemampuan klasifikasi kelompok kontrol berdistribusi normal. Pada post-test kelompok kontrol diperoleh $D_{\text {hitung sebesar } 0,206 \text { dan } D_{\text {tabel }}}$ 0,327 , maka $D_{\text {hitung }}<D_{\text {tabel, }}$ artinya data post-test kemampuan klasifikasi anak kelompok kontrol berdistribusi normal.

Setelah dilakukan uji normalitas, dilanjutkan dengan uji homogenitas varians. Rumus yang digunakan adalah uji- 
$F$ dengan kriteria data homogen jika $F_{\text {hitung }}$ $<\mathrm{F}_{\text {tabel. }}$.

Adapun ringkasan hasil uji homogenitas varians data pre-test dan post-test kelompok eksperimen dan kelompok kontrol disajikan pada Tabel 5.

Tabel 5. Ringkasan Hasil Uji Homogenitas Kelompok Eksperimen dan Kelompok Kontrol

\begin{tabular}{cccc}
\hline Kelompok & $\mathrm{F}_{\text {hitung }}$ & $\mathrm{F}_{\text {tabel }}$ & Keterangan \\
\hline Pre-test & 1,07 & 2,29 & Homogen \\
Post-test & 1,95 & 2,39 & Homogen \\
\hline
\end{tabular}

Hasil uji homogenitas dengan uji-F menunjukkan $F_{\text {hitung }}$ pada pre-test sebesar 1,07 dan $F_{\text {tabel }}$ dengan $\mathrm{dk}_{\text {pembilang }}=15$, $\mathrm{dk}_{\text {penyebut }}=18$, dan taraf signifikansi $5 \%$ adalah 2,29 , maka $F_{\text {hitung }}<F_{\text {tabel, }}$ artinya varians data kemampuan klasifikasi pada pre-test kelompok eksperimen dan kelompok kontrol homogen. Sedangkan pada post-test diperoleh $F_{\text {hitung }}$ sebesar 1,95 dan $F_{\text {tabel }}$ dengan $\mathrm{dk}_{\text {pembilang }}=18$, $\mathrm{dk}_{\text {penyebut }}=15$, dan taraf signifikansi $5 \%$ adalah 2,39, maka $F_{\text {hitung }}<F_{\text {tabel, }}$, artinya varians data kemampuan klasifikasi pada post-test kelompok eksperimen dan kelompok kontrol adalah homogen.
Pengujian asumsi yang dilakukan memperoleh hasil bahwa data kemampuan klasifikasi anak kelompok eksperimen dan kelompok kontrol adalah normal dan homogen. Maka, dapat dilanjutkan dengan pengujian hipotesis. Pengujian hipotesis dilakukan menggunakan uji-t sampel independent dengan rumus polled varians. Dengan kriteria $\mathrm{H}_{0}$ ditolak jika $t_{\text {hitung }}>t_{\text {tabel }}$ dan $\mathrm{H}_{0}$ diterima jika $\mathrm{t}_{\text {hitung }}<\mathrm{t}_{\text {tabel }}$ pada taraf signifikansi $5 \%$ dengan $\mathrm{dk}=\left(\mathrm{n}_{1}+\mathrm{n}_{2}-2\right)$. Ringkasan hasil pengujian hipotesis disajikan pada Tabel 6 sebagai berikut.

Tabel 6. Ringkasan Hasil Pengujian Hipotesis

\begin{tabular}{cccccccc}
\hline Kelompok & $\mathrm{N}$ & $\mathrm{Dk}$ & $\mathrm{M}$ & Varians & $\mathrm{t}_{\text {hitung }}$ & $\mathrm{t}_{\text {tabel }}$ & Keterangan \\
\hline Eksperimen & 19 & \multirow{2}{*}{33} & 58,53 & 47,263 & \multirow{2}{*}{, 761} & 2,042 & $\mathrm{H}_{0}$ ditolak, \\
Kontrol & 16 & & 38,44 & 24,262 & & & \\
$\mathrm{H}_{1}$ diterima
\end{tabular}

Pengujian hipotesis dengan uji-t

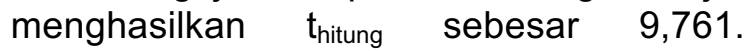
Sedangkan $t_{\text {tabel }}$ dengan $\mathrm{dk}=33$ pada taraf signifikansi $5 \%$ adalah 2,042. Ini berarti $t_{\text {hitung }}>t_{\text {tabel }}$, sehingga $\mathrm{H}_{0}$ ditolak dan $\mathrm{H}_{1}$ diterima. Dengan demikian, maka terdapat pengaruh yang signifikan metode edutainment terhadap kemampuan klasifikasi anak kelompok A Taman KanakKanak Gugus IV Kecamatan Buleleng Tahun Pelajaran 2017/2018. Perbandingan hasil perhitungan rata-rata kemampuan klasifikasi kelompok eksperimen adalah 58,53 lebih besar dari pada rata-rata kemampuan klasifikasi kelompok kontrol yaitu 38,44 .

Berdasarkan hasil pengujian hipotesis dengan uji-t diperoleh $t_{\text {hitung }}=9,761>t_{\text {tabel }}=$ 2,042 . Artinya terdapat pengaruh yang signifikan metode edutainment terhadap kemampuan klasifikasi anak. Hal ini didukung oleh rata-rata pada kelompok eksperimen yang lebih besar dari rata-rata pada kelompok kontrol $(58,53>38,44)$. Hasil tersebut menunjukkan bahwa kemampuan klasifikasi anak yang memperoleh pembelajaran dengan metode edutainment lebih baik dari kemampuan klasifikasi anak yang tidak memperoleh pembelajaran dengan metode edutainment.

Pembelajaran dengan metode edutainment melibatkan penyajian materi melalui video pembelajaran dan diaplikasikan melalui aktivitas bermain. Penyajian materi melalui video pembelajaran merupakan salah satu cara yang menarik dan dapat menumbuhkan perasaan senang pada anak. Ini tampak dari antusias dan perhatian anak ketika 
melihat dan menyimak video yang ditayangkan.

Setelah video ditayangkan, dilakukan diskusi terkait hal-hal yang terdapat pada video. Anak tampak semangat dalam menyampaikan apa saja yang dilihat dalam video. Ketika sesi diskusi, perkembangan anak sudah baik dalam menyebutkan ciriciri benda seperti bentuk, warna, atau ukuran benda. Ini menandakan bahwa pengenalan materi melalui video dapat menarik minat dan perhatian anak, sehingga anak fokus dan dapat memahami materi yang disampaikan. Pembelajaran yang menyajikan hal menarik dan menyenangkan dapat menimbulkan emosi positif, sehingga materi yang disampaikan dapat dipahami dengan lebih mudah oleh anak. Hal ini sesuai dengan pendapat Suyadi (2010:229) yang menyatakan "ketika suatu pelajaran melibatkan emosi positif yang kuat, umumnya pelajaran tersebut akan terekam dengan kuat pula dalam ingatan".

Pengetahuan yang diperoleh dari video kemudian diaplikasikan melalui aktivitas bermain. Aktivitas bermain dapat menciptakan suasana yang menyenangkan. Hal ini terlihat ketika anak aktif dan antusias dalam bermain. Tampak sikap dan rasa ingin tahu anak sangat tinggi terhadap cara menyelesaikan permainan. Ketika anak belum tepat dalam memenuhi instruksi permainan yaitu mengklasifikasikan benda, maka anak akan mengulanginya sampai berhasil. Dari hal tersebut terlihat bahwa anak sangat menikmati permainan yang tidak lain merupakan proses pembelajaran, tanpa merasa bahwa ia sedang belajar. Hal ini disebabkan karena terciptanya suasana yang menyenangkan sehingga anak tidak mudah merasa bosan. Ini sejalan dengan pendapat Hamid (2011:20) yang menyatakan bahwa edutainment adalah suatu cara untuk membuat proses pendidikan dan pengajaran bisa menjadi begitu menyenangkan, sehingga para siswa dapat dengan mudah menangkap esensi dari pembelajaran itu sendiri, tanpa merasa bahwa mereka tengah belajar.

Berbekal pengetahuan yang diperoleh melalui video, ketika aktivitas bermain anak terlihat sudah mampu menunjukkan benda- benda yang memiliki ciri-ciri sama. Anak juga sudah mampu membedakan benda berdasarkan bentuk, warna, ukuran, atau 2 variasi. Dalam memilah benda-benda yang tidak sama, kemampuan anak sudah berkembang dengan baik. Begitu pula pada kegiatan mengelompokkan benda-benda yang sama, baik 1 atau 2 variasi, anak juga sudah memperlihatkan perkembangan yang baik. Hal tersebut juga tampak berdasarkan hasil analisis data yang menunjukkan kemampuan klasifikasi anak meningkat dari rata-rata pada pre-test yang termasuk kategori sangat rendah ke post-test yang rata-ratanya termasuk dalam kategori sangat tinggi. Hasil penelitian ini sejalan dengan penelitian yang dilakukan Rosdiana (2015) yang menyatakan bahwa aktivitas bermain dengan media alam memberikan pengaruh terhadap peningkatan kemampuan kognitif anak dalam mengklasifikasikan benda.

Peningkatan kemampuan klasifikasi anak pada penelitian ini disebabkan karena metode edutainment memiliki kelebihan yaitu menyajikan pembelajaran yang menarik dan menyenangkan dengan memadukan unsur pendidikan dan hiburan. Metode edutainment juga melibatkan tiga modalitas belajar, yaitu auditori, visual, dan kinestetik. Dengan dilibatkan tiga modalitas belajar tersebut, materi pembelajaran akan lebih mudah dipahami oleh anak. Hal ini didukung oleh pendapat Roqib (dalam Maghfuro dan Febrita, 2014:3) yang menyatakan bahwa kelebihan metode edutainment yaitu dapat membuat anak merasa senang, membuat belajar menjadi terasa lebih mudah, memperkuat pemahaman materi pembelajaran karena mendesain pembelajaran dengan pemberian selipan humor atau permainan edukatif.

Berbeda halnya dengan kelompok kontrol yang tidak menggunakan metode edutainment, dimana materi dikenalkan oleh guru secara lisan dengan bantuan media seperti balok dan gambar. Kemudian kegiatan yang dilakukan anak adalah menyelesaikan tugas terkait dengan klasifikasi di meja masing-masing. Pada saat kegiatan klasifikasi, anak masih belum memahami dengan baik ciri-ciri, persamaan dan perbedaan benda, serta cara memilah 
dan mengelompokkan benda sesuai dengan karakteristiknya. Ini tampak ketika anak masih menggabungkan benda dengan ciri-ciri berbeda ke dalam kelompok yang sama. Hasil penelitian di kelompok kontrol menunjukkan adanya peningkatan, namun rata-ratanya masih termasuk dalam kategori rendah.

Berdasarkan pembahasan hasil penelitian di atas, dapat disimpulkan bahwa terdapat pengaruh yang signifikan metode edutainment terhadap kemampuan klasifikasi anak kelompok A Taman KanakKanak Gugus IV Kecamatan Buleleng Tahun Pelajaran 2017/2018. Hal ini berarti metode edutainment dapat dijadikan salah satu alternatif metode pembelajaran yang tepat dalam menstimulasi kemampuan klasifikasi anak.

\section{PENUTUP}

Berdasarkan pemaparan dan pembahasan hasil penelitian, maka dapat disimpulkan bahwa terdapat pengaruh yang signifikan metode edutainment terhadap kemampuan klasifikasi anak kelompok A Taman Kanak-Kanak Gugus IV Kecamatan Buleleng Tahun Pelajaran 2017/2018. Hal ini tampak dari hasil pengujian hipotesis dengan uji-t diperoleh hasil $t_{\text {hitung }}$ sebesar 9,761 dan $t_{\text {tabel }}$ dengan taraf signifikansi $5 \%$ dan dk $\left(\mathrm{n}_{1}+\mathrm{n}_{2}-2=33\right)$ adalah 2,042. Hasil tersebut menunjukkan bahwa $t_{\text {hitung }}>$ $t_{\text {tabel}}$, yaitu $9,761>2,042$, sehingga $\mathrm{H}_{0}$ ditolak dan $\mathrm{H}_{1}$ diterima. Maka, terdapat pengaruh yang signifikan metode edutainment terhadap kemampuan klasifikasi anak kelompok A Taman KanakKanak Gugus IV Kecamatan Buleleng Tahun Pelajaran 2017/2018.

Adanya pengaruh yang signifikan metode edutainment terhadap kemampuan klasifikasi anak menandakan bahwa metode edutainment tepat dijadikan alternatif metode pembelajaran untuk mengembangkan kemampuan klasifikasi anak usia dini.

Terdapat beberapa hal yang disarankan pada penelitian ini. Yang pertama, kepada guru disarankan agar lebih memperdalam referensi mengenai metode-metode yang dapat menstimulasi kemampuan klasifikasi anak khususnya metode edutainment, sehingga guru akan lebih terbantu dalam mengembangkan kemampuan klasifikasi anak. Yang kedua, kepada sekolah, hasil penelitian ini dapat dijadikan bahan pertimbangan dalam merancang proses pembelajaran yang dapat mengembangkan kemampuan anak secara optimal, khususnya pada kemampuan klasifikasi. Pihak sekolah dapat mempertimbangkan dari segi durasi pembelajaran dan juga metode yang sesuai. Sehingga tujuan pihak sekolah dalam mengoptimalisasi perkembangan anak dapat terwujud dengan baik. Yang ketiga, kepada peneliti lain disarankan agar mampu mengembangkan metode edutainment untuk menstimulasi kemampuan klasifikasi anak lebih mendalam dari segi faktor yang belum tercakup dalam penelitian ini.

\section{DAFTAR RUJUKAN}

Ambara, Didith Pramunditya, dkk. 2014. Asesmen Anak Usia Dini. Yogyakarta: Graha IImu.

Antara, Putu Aditya. 2015. "Pengembangan Bakat Seni Anak pada Taman KanakKanak". Visi, Volume 10, Nomor 1 (hlm. 33).

Beaty, Janice J. 2013. Observasi Perkembangan Anak Usia Dini. Terjemahan Arif Rakhman. Observing Development of the Young Child (Seventh Edition). tt. Jakarta: Kencana.

Fadlillah, M., dkk. 2014. Edutainment Pendidikan Anak Usia Dini: Menciptakan Pembelajaran Menarik, Aktif, dan Menyenangkan. Jakarta: Kencana.

Fauziddin, Moh. 2015. "Peningkatan Kemampuan Klasifikasi Melalui Media Benda Konkret pada Anak Kelompok A1 di TK Cahaya Kembar Bangkinang Kampar". Tersedia pada http://academia.edu/28337514/Pening katan_Kemampuan_Klasifikasi_Melal ui_Média_Benda_Konkret_pada_Ana k_Kelompok_A1_di_TK_Cahaya_Kem 
bar_Bangkinang_Kampar (diakses tanggal 30 Maret 2018).

Hamid, Sholeh. 2011. Metode Edutainment. Yogyakarta: Diva Press.

Jamaris, Martini. 2005. Perkembangan dan Pengembangan Anak Usia Taman Kanak-Kanak. Jakarta: Universitas Negeri Jakarta.

Maghfuro, Fatikhatul dan Febrita Ardianinsih. $2014 . \quad$ "Metode Edutainment Bermedia Video Terhadap Hasil Belajar IPA Anak Autis di Kelas Khusus SDNP Surabaya". Tersedia pada http://jurnalmahasiswa.unesa.ac.id/arti cle/11622/15/article.pdf (diakses tanggal 10 Februari 2018).

Peraturan Menteri Pendidikan dan Kebudayaan Republik Indonesia Nomor 137 Tahun 2014 tentang Standar Pendidikan Anak Usia Dini. 2015. Jakarta: Kementerian Pendidikan dan Kebudayaan.

Putala, Wioleta Kopek dan Martin Bilek. 2016. "The Use of "Entertainment Education" in Teaching Chemistry, Taking into Account Pupils With Special Educational Need". Tersedia pada http://up.krakow.pl (diakses tanggal 12 Februari 2018).

Rosdiana. 2015. "Pengaruh Aktivitas Bermain dengan Media Alam Terhadap Kemampuan Kognitif Mengklasifikasikan Benda". Tersedia pada

http://download.portalgaruda.org/articl e.php (diakses tanggal 5 April 2018).

Suyadi. 2010. Psikologi Belajar PAUD. Yogyakarta: Pedagogia.

Tirtayani, dkk. 2014. Buku Ajar Matematika untuk Anak Usia Dini. Singaraja: Universitas Pendidikan Ganesha.

Wibawati, Arisnani. 2014. Peningkatan Kemampuan Klasifikasi Melalui Media Benda Konkret Pada Anak
Kelompok A1 di RA Al Husna Pakualaman Yogyakarta, Skripsi (tidak diterbitkan). Program Studi Pendidikan Guru Pendidikan Anak Usia Dini, Universitas Negeri Yogyakarta. 